\title{
Occurrence of the fish Girardinichthys viviparus (Cyprinodontiformes: Goodeidae) in an urban lake at Mexico City
}

\author{
José Luis Gómez-Márquez, Bertha Peña-Mendoza and José Luis Guzmán-Santiago \\ Laboratorio de Limnología, Facultad de Estudios Superiores Zaragoza, UNAM. México, D.F. Fax 77301 51; \\ Igomez@servidor.unam.mx; berthapegna@yahoo.com.mx
}

Received 20-IV-2012 Corrected 16-VIII-2012 Accepted 28-IX-2012

\begin{abstract}
A population of the Chapultepec splitfin Girardinichthys viviparus was found in the urban Lake Alameda Oriente. Biometry data for females and males are presented for first time for this population. The main causes of risk reported for this species in the aquatic system are water depletion and habitat alteration by treated wastewater used to keep the water level in the lake.
\end{abstract}

KEY WORDS

Freshwater, urban lake, threatened species, fish.

\section{RESUMEN}

Una población del mexclapique Girardinichthys viviparus fue observada en el lago urbano Alameda Oriente. Se incluye información sobre la biometría de hembras y machos por primera vez para este lago urbano de la ciudad de México. Las principales causas de riesgo reportadas para esta especie en este cuerpo de agua son la disminución del volumen de agua y la alteración de hábitat por el uso de aguas de desechos tratadas con el fin de mantener el nivel de agua del lago.

\section{PALABRAS CLAVE}

Agua dulce, lago urbano, especie amenazada, peces.
Mexico is among the five countries in the world with the highest biological diversity, not only because it has a large number of species, but also in terms of other aspects such as ecosystem and genetic variability (Neyra \& Duran, 1998; Bezaury et al., 2000). In addition, the Mexican territory includes areas whose biodiversity is poorly known (CONABIO, 2002). The Family Goodeidae is between the most important Mexican freshwater fishes. This fish are characterized by sexual dimorphism, courtship and viviparity, which led to a series of morphological, anatomical and physiological characteristic of the group (Díaz-Pardo \& Ortíz-Jiménez, 1986). The Goodeidae family is represented in Mexico by approximately 42 species of viviparous fish (Paulo-Maya \& Trujillo-Jiménez, 2000), includes 36 livebearing species largely confined to the Rio Lerma basin in the highlands of Central Mexico (Espinosa et al., 1993; Moyle \& Cech, 2000; Miller et al., 2005; De la Vega-Salazar, 2006). At present, the mexclapique or Chapultepec splitfin (Girardinichthys viviparus) is endemic to the basin of Mexico: Lakes Xochimilco, Zumpango, Texcoco, Chapultepec
(Alvarez del Villar \& Navarro, 1957, cited in Sedeño-Díaz \& López-López, 2009). Although Espinosa et al. (1993) cited G. viviparus as endemic to the Valley of Mexico, also there are records that indicate their presence in the upper basin of Pánuco in the Tula River (Alvarez del Villar, 1970; Díaz 2002) and Lake Tecocomulco (Miranda et al., 2008).

In Mexico, there has been no detailed limnological study (Arredondo-Figueroa \& Flores-Nava, 1992; Martinez-Arroyo \& Jáuregui, 2000; Schueler \& Simpson, 2001), despite the biological and economic importance in many inland water bodies and mainly in urban areas, and such bodies of water have been modified by the constant supply of nutrients (Quirós, 2007).

Urban lakes are important aquatic environments for large cities, because they are recreation areas (Labounty, 1995; Elías-Fernández et al., 2006). They are very different from other lakes: shallow, large, deep and characterized by particular depth, drained/surface water relationship, water balance, nutrient cycling and trophic status. They 
are also highly artificial and often hypertrophic yet more people come into contact with them than with rural, natural lakes. This aquatic system has received little attention in the limnological and watershed management literature, and our knowledge of their ecology and management is poor (Birch \& McCaskie, 1999; Schueler \& Simpson, 2001; Espinosa-Castillo, 2008).

Nowadays the urban lakes in Mexico City continue to play an important societal role as sources of fisheries, cultural and recreation, and they are highly valued by the Mexican people. They are also of great interest to aquatic scientists, having unique limnological and biotic characteristics and supporting numerous endemic species. We present a short communication on a threatened freshwater fishes from central Mexico.

\section{METHODOLOGY}

During an ongoing study of environmental quality and biota of Lake Alameda Oriente, a total of 281 fishes were collected in two peripheral areas of Lake Alameda Oriente $\left(19^{\circ} 26^{\prime} 05,1^{\prime \prime} \mathrm{N} ; 99^{\circ} 03^{\prime} 18,3^{\prime \prime} \mathrm{W}\right)$ at 2234 in elevation. In March 2008, with a seine $5 \mathrm{~m}$ long and 1,0m deep, with $5 \mathrm{~mm}$ mesh, 81 specimens were fixed in 10\% formaldehyde. Specimens were then transported to the laboratory; measurements were made by vernier callipers reading to $0,1 \mathrm{~mm}$ and weighed to the nearest $0,01 \mathrm{~g}$ and dissected to determine sex. Some specimens were returned to the water. The sex ratio was analyzed for the whole population. The statistical significance of the ratio results was established by a goodness of fit Chi-squared test $\left(X^{2}\right)$.

A covariance analysis (ANCOVA, $p<0,05$ ) was conducted to determine whether or not there were significant differences for the length-weight relationship between both sexes. The Total length (TL)-total body weight (TW) relationship was calculated by a power regression between these variables for each sex using the formula:

$$
\mathrm{TW}=\mathrm{aTL}{ }^{\mathrm{b}}
$$

Where TW is the body weight, TL the total length, $b$ the growth exponent or length-weigh factor, and $a$ is a constant. The values of $a$ and $b$ were estimated by means of $a$ linearized form of that equation by taking (base 10) logarithms on both sides and estimating the values of $\log (a)$ and $\log (b)$ by means of a linear regression, using ordinary least-squares regression. Student's $t$-test was used to the hypothesis of isometric growth (Pauly, 1984). The catalogue number of voucher specimens is IB-UNAM 14728.

\section{RESULTS}

Among the fishes captured, 81 specimens of Chapultepec splitfin Girardinichthys viviparus (Bustamante, 1837) were identified following the descriptions provided in previous publications (Alvarez del Villar, 1970; Radda \& Meyer, 2003; Miller et al., 2005) such as the black colour of the breeding male; the presence of 18-26 rays in the anal fin; dark blotch above anus small and inconspicuous or absent; fin base longer than longest rays and dorsal and anal base with the same length in males; rudimentary gonopodium with 6-8 anal branched and short rays, separated by notch from remainder of fin. Diagnosis and measurements are given in Table 1. Some specimens were deposited in the Laboratorio de Peces del Instituto de Biología, UNAM., in order to check the identity of the species.

These data constituting the first record of total body length ( $\mathrm{TL})$, standard body length (SL), and body weight (TW) for males and females of this species in the urban lake. Total body length and weight ranged from 18 to 49 $\mathrm{mm}$ and 0,07 to $1,92 \mathrm{~g}$ for males, and from 20 to $61 \mathrm{~mm}$ and 0,06 to $3,98 \mathrm{~g}$ for females. Females were larger than males (t-student=10,78, $p<0,05$ ) (Fig. 1).

Of the 81 adults specimens dissected, 24 (29,6\%) were males and $57(70,4 \%)$ were females. The sex ratio of the catch as a whole was 2,4:1 (female:male), significantly different from a 1:1 ratio (Chi squared $=13,44, p<0,05$ ). The females dominated significantly in this aquatic system in the monitoring.

Length-weight relationship: This relation was evaluated for all individuals, and for each sex separately (females and males), although there is not significant difference between the male and female slopes of TW-TL regressions (ANCOVA $\mathrm{F}=0,18, p>0,05)$. These equations are given below:

$$
\begin{array}{ll}
\text { Females: } & \mathrm{TW}=0,000003 \mathrm{TL}^{3,445} ; R^{2}=0,980, \mathrm{p}<0,05 \\
\text { Males: } & \mathrm{TW}=0,000006 \mathrm{TL}^{3,267} ; R^{2}=0,937, \mathrm{p}<0,05 \\
\text { All fishes: } & \mathrm{TW}=0,000004 \mathrm{TL}^{3,402} ; R^{2}=0,975, \mathrm{p}<0,05
\end{array}
$$

Weight increased allometrically with size (Fig. 2), since b value had a significant difference from 3 (t-student $=8,049$, $p<0,05$ for females, and t-student $=2,816, p<0,05$ for males). For the same length, females weight were equals than males.

\section{DISCUSSION}

The specimens collected in Lake Alameda Oriente were bigger than those reported by Miranda et al. (2008) and Sedeño-Díaz \& López-López (2009). Probably, in this aquatic system the fishes have good environmental 
TABLE 1

Lengths ( $\mathrm{mm}$ ), weight $(\mathrm{g})$ and meristic traits of Girardinichthys viviparus specimens studied from Lake Alameda Oriente, distinguishing males $(n=24)$ and females $(n=57)$.

\begin{tabular}{lcccccccc}
\hline & TL $(\mathrm{mm})$ & $\mathrm{SL}(\mathrm{mm})$ & $\mathrm{BW}(\mathrm{mm})$ & $\mathrm{D}$ & $\mathrm{P}$ & $\mathrm{V}$ & $\mathrm{A}$ & $\mathrm{C}$ \\
\hline Females & $35,9 \pm 9,7$ & $30,6 \pm 8,7$ & $8,4 \pm 3,4$ & $19 \pm 0,8$ & $16 \pm 0,5$ & $6 \pm 0,4$ & $20 \pm 1,1$ & $29 \pm 1,9$ \\
& $(20-61)$ & $(17-53)$ & $(4-17)$ & $(18-21)$ & $(15-16)$ & $(5-6)$ & $(18-23)$ & $(24-31)$ \\
\multirow{2}{*}{ Males } & $27,7 \pm 6,9$ & $23,1 \pm 6,2$ & $5,7 \pm 2,6$ & $19 \pm 1,0$ & $16 \pm 0,5$ & $6 \pm 0,2$ & $20 \pm 1,0$ & $27 \pm 1,8$ \\
& $(18-49)$ & $(15-42)$ & $(3-13)$ & $(18-20)$ & $(15-16)$ & $(5-6)$ & $(19-22)$ & $(24-30)$
\end{tabular}

Values are means \pm S.D., range in parentheses.

TL: total length; SL: standard length; BW: body weight; D: dorsal fin rays; P: pectoral fin rays; V: ventral fin rays; A: anal fin rays; C: caudal fin rays.

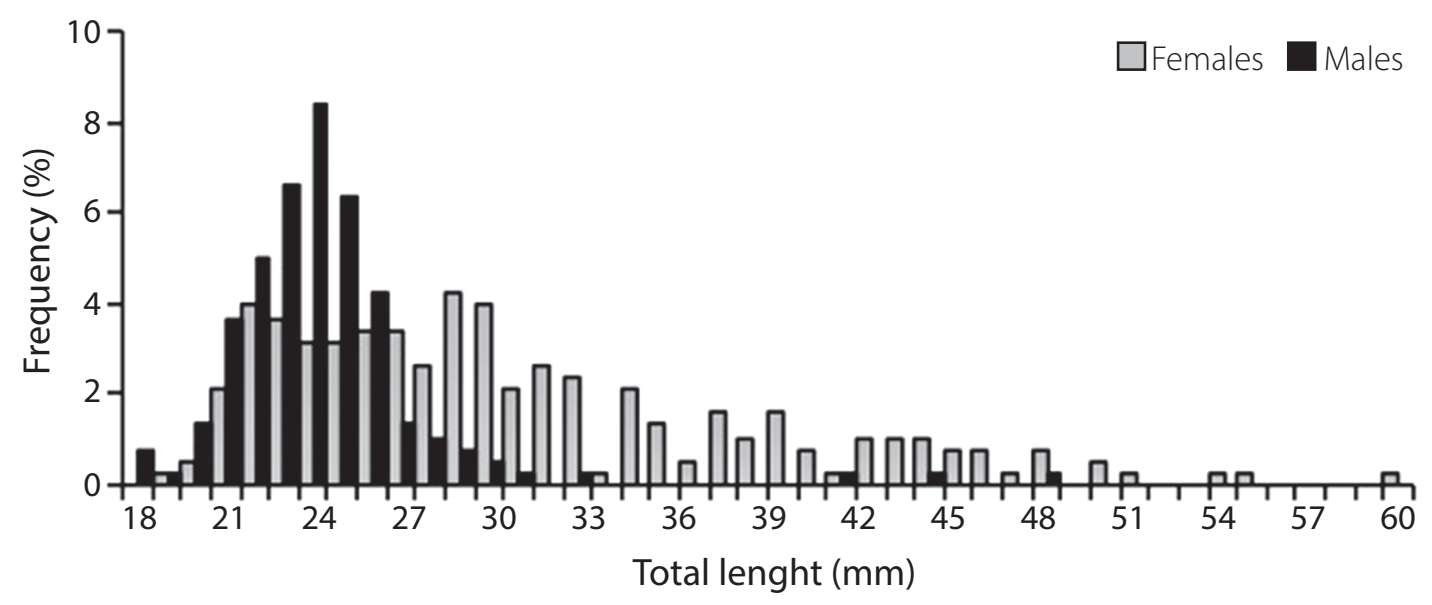

FIG. 1. Length-frequency distribution of Girardinichthys viviparus at Alameda Oriente urban lake, Mexico City.

and trophic condition to survive, they have to adapt to a stressful environment for the type of treated wastewater used to keep the lake level, mainly in dry season.

Nikolsky (1963) mentioned that the larger sizes of females result from a differential growth rate with respect to males. In our study, females probably have higher survivorship rates due to their larger size, are longer-lived than males, and are more resistant to the rigors of reproductive effort. Cházaro (1989) cited that the larger size of Chirostoma jordani is influenced by changes in the food supply and represents an adaptive response of the population to environmental changes, as in this urban lake occurred.

Sex ratio for G. viviparus in Alameda Oriente urban lake indicates that males and females have different abundances, and in this case deviation from the expected 1:1 (male:female) was significant. Nikolsky (1963) pointed out that the sex ratio varies considerably from one species to another, but in the majority of cases it is close to one, and may vary from one year to the next in the same population. Moreover, in this study the female:male sex ratio was 2,4:1 and variations in sex ratio could reflect natural population dynamics.

With respect to a differential sex distribution, van Aerle et al. (2004), Devlin \& Nagahama (2002) and Guerrero-Estévez \& Moreno-Mendoza (2010) pointed out that there is a large variety of mechanisms of sexual determination. In addition, van Aerle et al. (2004) cited that there are a wide range of chemicals discharged into the environment 



FIG. 2. Length-weight relationship for females (A) and males (B) of Girardinichthys viviparus.

that mimic hormones, especially estrogens, and sex steroids play an important role in the regulation of sexual differentiation, and this could be affect to the population.

Respect to the relationship between length and weight, Ricker (1979) mentioned that when fish have a b coefficient value significantly different from three, the growth is allometric. This is the case of the present study, body grows slower in length than weight, and an exponent more greater than 3 would indicate that the fish becomes heavier as it increases in size. Probably in this aquatic system the population has acceptable conditions of food. In addition, the relationship between length and weight provides an index frequently used by fisheries biologists to quantify the state of well-being of a fish (Wootton, 1990).
Lake Alameda Oriente is an artificial water body in the basin of Valle de Mexico. This basin covered the region that now is the modern Mexico City and environments. The other former bodies of water that formed the Gran Cuenca now are either greatly altered or extremely contaminated by secondarily-treated wastewater (ElíasFernández et al., 2006).

Lake Alameda Oriente varies from 8 to 9 ha, depending on the quantity of seasonal rainfall and domestic wastewater that receives. The lake has turbid and shallow waters, normally with $0,5-1,5 \mathrm{~m}$ maximum depth. Water temperature between 16 to $25^{\circ} \mathrm{C}$, dissolved oxygen range from 0,63 to $24,9 \mathrm{mg} / \mathrm{l}, \mathrm{pH}$ alkaline (mean 9,8 units), sodium, bicarbonates, carbonates and sulphates are the 
dominant ions and bigger proportions of calcium, and magnesium are present (Montaño, 2010).

The natural distribution of G. viviparus was restricted to two localities in the central and southern parts of the central basin of Mexico, Lakes Texcoco and Zumpango (Miller et al., 2005). According to literature, G. viviparus has been reported around of Mexico City, Lake Chalco, Lake Xochimilco, Lake Chapultepec, Requena reservoir, and Lake Texcoco (Navarrete et al., 2003). Recently this species has been discovered and reported by Miranda et al. (2008) in Lake Tecocomulco, Hidalgo, which is the only remaining natural water body in the Valle de Mexico basin (Caballero et al., 1999). However, Navarrete et al. (2003), Navarrete et al. (2004) and Sedeño-Díaz \& López-López (2009) mentioned that $G$. viviparus is known to be extinct in Lake Zumpango and Requena reservoir, as a result of receives domestic and industrial wastewater.

Direct anthropogenic effects have altered and contaminated its natural environment (Contreras-Balderas et al., 2003; Navarrete et al., 2004; Contreras-Balderas, 2005; De la Vega-Salazar, 2006) and in particular as a result of water exploitation for urban, agricultural and industrial needs (Díaz-Pardo \& Ortíz-Jiménez, 1986; De la Vega-Salazar, 2006). Furthermore, it is under considerable pressure from a range of anthropogenic activities, including water extraction for consumption, habitat degradation by pollution, reductions in surface water levels and the introduction of exotic species mainly (Soto-Galera \& Paulo, 1995; Lyons et al., 1998; Contreras-Balderas, 2005; De la Vega-Salazar \& Macías-García, 2005; Contreras MacBeath \& Rivas, 2007).

G. viviparus is an endangered goodeid with an extremely reduced range of distribution in the Mexican plateau, only known from a few locations near to Mexico City (Navarrete et al., 2003; Navarrete et al., 2004). This species has been catalogued as part of the numerous threatened freshwater fishes of Mexico (Williams \& Miller, 1990; Contreras-Balderas et al., 2003; Contreras-Balderas, 2005; Sedeño-Díaz \& López-López, 2009; Diario Oficial, 2010).

Nowadays, this species appears to be abundant in Lake Alameda Oriente, but due to the protected status of the species an attempt was made at this time to provide a more precise estimation of population biology with the not many data obtained. The greatest threats to the longterm existence of G. viviparus in the lake emerge from tourist activities and their effect on the lake habitat such as irrigation for surrounding fields. Lake Alameda Oriente should be protected as it hosts the largest population of $G$. viviparus ever discovered. Urgent conservation and management measures are needed to preserve both the volume of the body of water and its quality as a natural habitat for this species.
In all countries, a conservation strategy should be developed to protect remaining natural communities that support a relatively intact native fish fauna. The introduction and establishment of non-native species have resulted in severe declines of native fishes in México (ContrerasBalderas, 2005; Contreras MacBeath \& Rivas, 2007).

Canonico et al. (2005), Gozlan (2008) and Schlaepfer et al. (2011) mentioned that non-native species can cause the loss of biological diversity (i.e., genetic, species, and ecosystem diversity) and threaten the well-being of humans when they become invasive. However, in some cases, they can also provide conservation benefits. Non-native species can also have desirable effects on an ecosystem. Numerous species have been repeatedly and deliberately introduced outside their native range for agricultural, ornamental, aquaculture and recreational purposes. As a result non-native species are integral to the culture and economies of most countries.

Freshwater ecosystems in Mexico are specifically vulnerable due to degradation and exploitation to be subject, making it difficult to establish conservation strategies for species of this family. However, it is necessary to recognize the importance of developing specific programs to protect water quality and habitat, and to ensure the conservation of flora and fauna of freshwater. The destruction of biotopes all around Mexico City is dramatic and gets worse rapidly. The last surviving fish species endemic to the basin of Mexico requires urgent protection of its population as cited by Miranda et al. (2008) and Sedeño-Díaz \& López-López (2009).

\section{ACKNOWLEDGMENTS}

This work received support from FES Zaragoza, UNAM, Mexico. We are indebted to L.C. Huidobro for the support in to identify of species. B.O. Castillo and L.G. Montesino assisted in the collection and measurement of the fish, and two anonymous reviewers for discussion and comments on previous versions of this manuscript.

\section{REFERENCES}

Álvarez del Villar, J. (1970). Peces Mexicanos (Claves). Comisión Nacional Consultiva de Pesca. Instituto Nacional de Investigaciones Biológico Pesqueras. S.I.C.: México.

Arredondo-Figueroa, J.L. \& Flores-Nava, A. (1992). Características limnológicas de pequeños embalses epicontinentales, su uso y manejo en la acuacultura. Hidrobiológica 3/4, 1-10.

Bezaury, C.J.E., Waller, R., Sotomayor, L., Anderson, S., Sayre, R. \& Houseal, B. (2000). Conservation of biodiversity in Mexico: 
Ecoregions, sites and conservation targets. The Nature Conservancy Mexico, Division, Conservation Science and Stewardship: Mexico.

Birch, S. \& McCaskie, J. (1999). Shallow urban lakes: a challenge for lake management. Hydrobiologia 395/396, 365-377.

Caballero, M., Lozano, S., Ortega, B., Urrutia, J. \& Macias, J.L. (1999). Environmental characteristics of Lake Tecocomulco, northern basin of Mexico, for the last 50,000 years. Journal of Paleolimnology 22, 399-411.

Canonico, C.G., Arthington, A., Mccrary, K.J. \& Thieme, L.M. (2005). The effects of introduced tilapias on native biodiversity. Aquatic Conservation. Marine Freshwater Ecosystems 15, 463-483

Cházaro O.S. (1989). Estudio sobre algunos aspectos de la Biología del charal Chirostoma jordani en el embalse Trinidad Favela, Edo. de México. Tesis de Licenciatura. ENEP-Iztacala. UNAM: México.

CONABIO (Comisión Nacional para el Conocimiento y Uso de la Biodiversidad). (2002). Lista de regiones hidrológicas prioritarias. Retrieved from http://www.conabio.gob.mx/ conocimiento/regionalizacion/doctos/Hlistado.html

Contreras-Balderas, S. \& Almada-Villela, P. (1996). Girardinichthys viviparus. IUCN Red List of Threatened Species. Retrieved from www.iucnredlist.org

Contreras-Balderas, S., Almada-Villela, P., Lozano-Vilano, M.L. \& García-Ramírez, M.E. (2003). Freshwater fish at risk or extinct in México. A checklist and review. Reviews in Fish Biology and Fisheries 12, 241-251.

Contreras-Balderas, S. (2005). Conservation Status of Mexican Freshwater Viviparous Fishes. In Viviparous Fishes. New Life Publications: México.

Contreras-MacBeath, T. \& Rivas, J.M. (2007). Threatened fishes of the world: Notropis boucardi (Günther 1868) (Cyprinidae). Environmental Biology of Fishes 78, 287-288. doi: 10.1007/ s10641-006-0039-8.

De la Vega-Salazar, M.Y. \& Macías-García, C. (2005). Principal Factors in the Decline of the Mexican Endemic Viviparous Fishes (Goodeinae: Goodeidae). In Viviparous Fishes. New Life Publications: México.

De la Vega-Salazar, M.Y. (2006). Estado de conservación de los peces de la familia Goodeidae (Cyprinodontiformes) en la mesa central de México. Revista Biología Tropical 54, 163-177.

Devlin, H.R. \& Nagahama, Y. (2002). Sex determination and sex differentiation in fish: an overview of genetic, physiological, and environmental influences. Aquaculture 208, 191-364.

Diario Oficial. (2010). Norma Oficial Mexicana NOM-059-SEMARNAT-2010. Protección ambiental-Especies nativas de México de flora y fauna silvestres-Categorías de riesgo y especificaciones para su inclusión, exclusión o cambio-Lista de especies en riesgo. Diario oficial: México, D.F.
Díaz-Pardo, E. \& Ortiz-Jiménez, D. (1986). Reproducción y ontogenia de Girardinichthys viviparus (Pisces: Goodeidae). Anales de la Escuela Nacional de Ciencias Biológicas 30, 45-66.

Díaz, P.E. (2002). Girardinichthys viviparus. Peces en riesgo de la Mesa Central de México. Laboratorio de Ictiología y Limnología, Departamento de Zoología, Escuela Nacional de Ciencias Biológicas, Instituto Politécnico Nacional. Bases de datos SNIB-CONABIO. Proyecto W039: México. D.F., Mexico. Retrieved from http://www.conabio.gob. $\mathrm{mx} /$ conocimiento/ise/fichasnom/Girardinichthysviviparus00.pdf

Elías-Fernández, G., Navarrete-Salgado, N.A., FernándezGuzmán, J.L \& Contreras-Rivero, G. (2006). Crecimiento, abundancia y biomasa de Poecilia reticulata en el lago urbano del parque Tezozomoc de la ciudad de México. Revista Chapingo. Serie ciencias forestales y del ambiente $12,155-159$.

Espinosa, P.H., Gaspar, M.T.D. \& Fuentes, P.M. (1993). Listado Faunístico de México. III. Los peces dulceacuícolas mexicanos. Instituto de Biología, UNAM: México.

Espinosa-Castillo, M. (2008). Procesos y actores en la conformación del suelo urbano en el ex lago de Texcoco. Economía. Sociedad y Territorio VIII (27): 769-798.

Guerrero-Estévez, S. \& N. Moreno-Mendoza. 2010. Sexual determination and differentiation in teleost fish. Reviews in Fish Biology and Fisheries 20, 101-121. doi: 10.1007/ s11160-009-9123-4

Gozlan, R.E. (2008). Introduction of non-native freshwater fish: is it all bad?. Fish and Fisheries 9, 106-115.

Labounty, J. (1995). What's an urban lake worth? Lakeline 15, 6-7.

Lyons, J., González-Hernández, G., Soto-Galera, E. \& Guzmán-Arroyo, M. (1998). Decline of freshwater fishes and fisheries in selected drainages of best-central Mexico. Fisheries 23, 10-17.

Martínez-Arroyo, A. \& Jáuregui, E. (2000). On the environmental role of urban lakes in Mexico City. Urban Ecosystems 4, 145-166.

Miller, R.R., Winckley, W.L. \& Norris, S.M. (2005). Freshwater fishes of México. The University of Chicago: Chicago, USA.

Miranda, R., Galicia, D., Pulido-Flores, G. \& Monks, S. (2008). First record of Girardinichthys viviparus in Lake Tecocomulco, Mexico. Journal of Fish Biology 73, 317-322. doi:10.1111/j.1095-8649.2008.01929.x

Montaño, S.I. (2010). Aspectos hidrobiológicos en dos esclusas del lago artificial del Parque de la Alameda Oriente. Tesis de Licenciatura, FES Zaragoza, UNAM: México.

Moyle, P.B. \& Cech, J.J. (2000). Fishes. An Introduction to Ichthyology. Prentice-Hall Inc: New Jersey, USA.

Navarrete, S.N.A., Contreras, G.R. \& Elias, G.F. (2003). Abundancia y estatus sanitario del mexclapique (Girardinichthys viviparus Bustamante) en cuerpos de agua del centro de 
México. Revista Chapingo. Serie ciencias forestales y del ambiente 9, 143-146.

Navarrete, S.N.A., Contreras, G.R., Elías, G.F. \& Rojas, M.L.B. (2004). Situación de Girardinichthys viviparus (especie amenazada) en los lagos de Chapultepec, Zumpango y Requena. Revista Zoologia 15, 1-6.

Neyra, G.L. \& Durand, L.S. (1998). Biodiversidad. In La diversidad biológica de México: Estudio de País, 1998. Comisión Nacional para el Conocimiento y Uso de la Biodiversidad: México.

Nikolsky, G.V. (1963). The Ecology of Fishes. Academic Press: New York. USA.

Paulo-Maya, J. \& Trujillo-Jiménez, P. (2000). Nueva especie de Ilyodon (Cyprinodontiformes:Goodeidae) de la cuenca del río Balsas, México. Revista de Biología Tropical 48, 465-472.

Pauly, D. (1984). Fish population dynamics in tropical waters: A manual for use with programmable calculators. International Center for Living Aquatic Resources Management, Studies and Reviews 8: Manila, Philippines

Quirós, R. (2007). Manejo y recuperación de lagos urbanos. Documento de Trabajo del Área de Sistemas de Producción Acuática No. 6. Facultad de Agronomía, Universidad de Buenos Aires: Argentina.

Radda, A.C. \& Meyer, M.K. (2003). Description of Girardinichthys ireneae sp.n. from Zacapu, Michoacan, Mexico, with remarks on the genera Girardinichthys Bleeker, 1860 and
Hubbsina De Buen, 1941 (Goodeidae, Pisces). Die Annalen des Naturhistorischen Museums in Wien, Serie B 104, 5-9.

Ricker, W.E. (1979). Growth rates and models. In Fish Physiology. Volume VIII. Academic Press: London, England.

Schlaepfer, A.M., Sax, F.D. \& Olden, D.J. (2011). The potential conservation value of non-native species. Conservation Biology 25(3), 428-437. doi: 10.1111/j.1523-1739.2010.01646.x

Schueler, T. \&Simpson, J. (2001). Why urban lakes are different. Urban Lakes Management 3, 747-750.

Sedeño-Díaz, J.E. \& López-López, E. (2009). Threatened fishes of the world: Girardinichthys viviparus (Bustamante 1837) (Cyprinodontiformes:Goodeidae). Environmental Biology and Fishes 84, 11-12.

Soto-Galera, E. \& Paulo, J.M. (1995). Peces dulceacuícolas Mexicanos. XI. Allotoca dugesii (Cyprinodontiformes: Goodeidae). Zoologia Informa, IPN 31, 5-15.

van Aerle, R., Runnalls, T.J. \& Tyler, C.R. (2004). Ontogeny of gonadal sex development relative to growth in fathead minnow. Journal of Fish Biology 64, 355-369. doi:10.1046/j.1095-8649.2003.00296.x

Williams, J.E. \& Miller, R.R. (1990). Conservation status of the North American fish fauna in fresh water. Journal of Fish Biology 37, 79-85.

Wootton, J.R. (1990). Ecology of teleost fishes. Fish and Fisheries Series 1. Chapman \& Hall: New York, USA. 
